\title{
The Application of Body Language in English Teaching
}

\author{
Yuanyuan Tai \\ School of Foreign Languages, Heze University, Heze, China
}

\begin{abstract}
In English teaching, with the constant reform of teaching methods, body language as a kind of nonverbal language plays a very significant role in the interaction between teachers and students. It not only can express the speakers' intention more accurately and effectively, simplify the teaching instruction, stimulate the students' interest, optimize the purpose of English teaching and enhance teaching effectiveness, but also can help improve the students' ability of listening, speaking, reading and so on. Through literature review, by inducing and summarizing, this paper did a survey on several kinds of body languages and their some aspects, such as their features, importance, etc. This paper aims at helping English teachers understand the application of body language in teaching, and encouraging them to try using body language in classes in order to assist their teaching. The English teachers in new times should use body language properly in their class teaching and bring its function in language teaching into full play to achieve the best teaching effects.
\end{abstract}

Index Terms — body language, English teaching, nonverbal language

\section{INTRODUCTION}

Now China's English education is undertaking reforms. Traditional education plays too much attention to instilling the knowledge into the students. Such cramming method of teaching brings up the students who have good marks but low ability. Today's English education requires students to communicate in English. Teachers are also required to teach English nearly without Chinese expression all the class time. However, because of the limitation of students' vocabulary, teachers should take some other effective ways to support English teaching. Body language can help to explain what the teachers mean. Teachers also can deepen students' understanding and memories with the aid of body language. When the communication between teachers and students becomes more and more important with the developing of English education, the use of body language can support teaching and help teachers get better teaching results.

As is known to all, classroom teaching is one kind of communicative activity between teachers and students. Some students are absent-minded, which may lead to the failure of communication in classroom. Apart from the students' subjective reasons, the teachers also have responsibility for this phenomenon. Teachers need to work hard to captive and sustain the attention of students in order to engage them to focus on the lessons. Actually, in some cases, nonverbal communication is more important than the verbal one in the communication between teachers and students. Such as known to all, volume, speed and tone of voice will stimulate the students' response directly. Human body language, as a nonverbal communication, including gestures and facial expressions, is actually often used to communicate in countless subtle and complex ways. In class, most of students are often more attentive to what teachers do than what they say. To arouse students' interest in learning English and to help them learn better, teachers have to try their best to think of as many ways as possible to motivate students' enthusiasm, and body language is one of them. In order to improve students' English mentalities, teachers should use Chinese sparingly, especially in the background of nowadays' quality-oriented education. And body language has become the necessary media. Body language of both teachers and students plays an active role in teaching English class. Teachers accompanied by gestures and facial expressions could create visual effects. It helps teachers express their own ideas and viewpoints more accurately and vividly to draw the attention of students. When teachers add body language to English teaching, students will be interested in learning English. What's more, students can learn to maintain long-term memory. This is a wonderful magic that body language has.

As we can see, in school education, body language plays a positive role not only in class teaching, but in shaping students' characters. Students often respect their teachers; even imitate teachers' words and actions, sometimes subconsciously. Therefore, teachers should understand the body language correctly, and master the methods and principles of body language stably. As an English teacher in the new times, we should help students grasp the foreign language with new teaching technique, and body language can take this role.

In one word, body language is helpful for English teaching. In this article, the theoretical study and application of body language will be discussed.

\section{A. Definition of Body Language}

Body language is a term for different forms of communication using body movements or gestures instead of, sounds, verbal language, or other ways of communication. Body language is the process of communicating what you are feeling 
or thinking by the way you place and move your body rather than by words (Hornby, 2006). Although we may not realize it when we talk with others and send messages to the people around us, we make ourselves understood not only by words, but also by facial expressions and body movements. We call it body language, which studies the meaning of all parts of body. It includes many nonverbal behaviors, e.g. eye contact, gestures, postures, facial gestures, touch, and so on. It can deliver different information, making a set of system which is the same as language signal (Yu Aihong, 2002). For example: A smile and handshake indicate welcome, waving one's hand means "goodbye", nodding the head is a way to show agreement while shaking it means disagreement. Body language is a kind of nonverbal communication and it forms parts of category of paralanguage, which describe all forms of human communication that are not verbal language.

\section{B. Features of Body Language}

\section{Intuitional feature}

Teachers use their facial expressions to afford information or give some commands in the classes. Using body language in English teaching can help teachers to deepen students' understanding and impression. Visual body language can arouse students' interests in English studying. For example, when the teacher teaches the word "cry", he or she can show a crying face. Teachers can get a more intuitional teaching result if they use body language properly.

\section{Communicative feature}

We cannot forget the importance of body language when teachers communicate with students. Students need to learn the communicative English, so they should be more active in the classroom teaching. Because traditional teaching method cannot arouse student' interests, we can create a comfortable and interesting atmosphere by the means of body language and put students in the central position in English learning. If teachers use their body language comfortably, they can assist the communication between with their students.

\section{Suggestive feature}

Actually sometimes students understand the English knowledge by guessing from teachers' body language. The students have rich imagination and they can get much information from teachers' body language. For example, when teachers design a communicative scene, they can take advantage of the vivid body language to help them imagine, which can give them a good context. In this way, can the students understand the text easily.

In a word, body language has proper features for English teaching. A qualified teacher should learn to use body language in English teaching. Body language can become a perceptible tool in the future education.

\section{NeCESSITIES AND IMPORTANCE OF Body LANGUAGE IN ENGLISH TEACHING}

English teaching is a very important part of the school education, and body language plays a positive role in cultivating the students' characters in school education. Body language is a significant means through which people get to know each other and communicate with each other. To be brief, body language is a kind of language through gestures, manners and countenances, which include eye contact, facial expression, and gestures and so on. As mentioned above, our nonverbal communication occupies almost 50 percent of our daily communication while words themselves take up only 7 percent. Our bodies put forward messages so often that sometimes we communicate a lot more than we realize (Chen \& Watts, 1992). The foreign language teachers are expected to perform actively in class, for example to dance joyfully, make vivid gesture as an actor. They are no longer expected to be kind and cultivated or just stand stubbornly on the platform (Guo Xuehua, 1999). In the current situation, there are three main aspects which is the need of body language in English teaching.

\section{A. Limitation of Students in English Vocabulary and Expressive Ability}

The English vocabulary is so abundant that the student cannot remember all of them. And students just can only grasp the words which are used frequently. According to the students' present level and practical situation, body language is required. Body language is one of rich expressive languages in the teaching language, especially in English teaching. Using body language suitably not only can avoid using Chinese to explain English, but also can promote teachers and students to communicate. In this way the teaching effectiveness will be enhanced. For instance, when a teacher wants his or her students to look at the blackboard, he or she just have to point at the blackboard, then the students will understand the order without difficulty despite the fact that they do not catch the key word "blackboard" clearly. Another example, when explaining the form "have done" such as "Have you found a job yet?" The teacher can use a normal speed when reading "we ought to use the form "have done", and read slowly when giving examples. Then a more effective way is to use hand gestures to emphasize when the teacher says "have done". He or she can reach out his or her index finger, pauses in the air while giving out the example. This action often makes a deep impression on students about the English language points.

\section{B. Less Interest of Students in English Class}

For a non-native learner, English learning is very boring. As the proverb goes "interest is the first teacher." No matter in any fields, a person to be successful, first of all, he must spend a lot of time and energy. Second, he must be interested in it. The strong study interest is the prime motive power of leaning activity. It can stimulate and raise students' study 
interest. Therefore, before each class, teachers should make good preparation to make sure that the students can have strong interest through a series of body language. For example, to teach: "What are you doing?" teachers can design the following body language for the context: let the students make the action of waiting, or dancing together with you. Students imitate the body language with teacher, listen and do warm up in the activities to enter the study condition, which can stimulate students' enthusiastic of learning greatly. In the classroom, teachers' behavior will influence students' leaning concentration. Sometimes teachers in their teaching with the use of body language can stimulate the students' interest.

\section{Depressing Atmosphere in English Teaching}

English is a foreign language to students and it is difficult to study well so that students cannot hold the interest in it for a long time. And when they cannot understand what teachers teach, they will not listen to the teachers. Then the atmosphere in English class is depressing. Meanwhile, if the sounds only stay in a horizontal line, students will soon lose their interest. And the rise meter can also affect students' mood. Teaching in order to arouse the attention of each student, teachers should glance around at the students. Teachers' body language attracts the attention of students, help students understand knowledge, and increase their enthusiasm. In this way, can teachers achieve the purpose of improving the teaching results.

In English classes, body language should be frequently used to improve the teaching effectiveness and develop the students' ability.

\section{SPECIFIC USE OF BODY LANGUAGE IN ENGLiSH TEACHING}

\section{A. Art of Using Facial Expressions}

Facial expression is a "universal language" in human being's society. Humans can show their feelings and emotions through facial expressions, such as happiness, sorrow, and fear. Therefore, teachers should know how to utilize different facial expressions to deal with different situations that appear in the classroom. If a teacher could use his facial expressions well, he would create good studying atmosphere and enhance his teaching effect.

For instance, when a student gives a wrong answer, will the teacher criticize him with an angry face or just encourage him with a smile? The answer is self-evident. English studying is comparatively difficulty for most students. Thus, teachers need to keep students optimistic and perky in English learning. To keep smiling has this magical function.

Some pedagogic professors proposed once, "Teachers should use smile with love to conquer a student's mind." A good English teacher should take the warm smile into classroom teaching. A warm smile could give students comfy studying surroundings. How does the teacher do this? Teachers can tell students some humorous stories in English or let them give some short role-plays. Teachers and students can keep their relationships under a happy and comfy atmosphere. A philosopher once said: "Education is important but it does not mean that teachers should keep a long face in the classroom." When students cannot focus their attention on the text, teachers can use some grandiloquent facial expressions to draw their attentions.

To sum up, if a teacher can use his facial expression diplomatically, he can receive a perfect classroom teaching result.

\section{B. Art of Using Gestures}

Teachers use appropriate gestures to transmit their minds and show their feelings. It adds persuasion and appeal to the class too.

In the classroom teaching, teacher can do some gestures for expressing what they want students to do. For instance, when a teacher gives the explanation for the sentence "He is fat", he may splay his hands around his haunch. If the sentence is "She is slim", teacher can give a curvaceous model as the letter S. Vivid gestures help students deepen their understanding of English.

Some other simple gestures act the role of conveying teachers' message. For instance, "Come here" (teacher stretches out one hand which points to himself with palm, then beckons), "It's OK" (with thumb upward) and so on.

Overall, gesture has most expressions in body language. Therefore, it has abundant expressions. However, teachers cannot use too fussy gestures to distract students' attentions.

\section{Art of Using Eye Contact}

Everyone knows that eye is the "window" to the soul. From one's eye, we can know his inner question and his attitudes. So, eye contact expresses exquisite emotion. The teacher uses his eye contact artistically to improve his teaching effects. Firstly, eye communication is between teachers and students. The teacher may catch students' regenerative information from their eye contacts. For instance, a student watches the ceiling with dull eyes every now and then, which means he gets side freaked. And if there is a doubt or sparkle in students' eyes, the teacher can know whether or not they have understood the content. That is to say, students' eyes can give some messages to teachers. The teacher should keep in good touch with students through their eye contacts.

However, how does the teacher use eye contact to help English teaching? The teacher may look around the whole class, which can let students feel the teacher's pertinence. If some students do not listen earnestly, the teacher also can 
prompt their attentions in the way. Teacher focuses partly on some students for helping them build up their self-confidence to study English and be more active in learning English. If a teacher has expressive eyes, he can control the class better.

\section{Art of Using Body Distance}

The distance between people still has informative meaning. Body distance is one kind of body language too. In the English classroom teaching, teachers stand in different positions which give students different feelings. Students indicate that when teachers stand near students two to three point five meters, that distance can produce one kind of control. If some students do not concentrate in the class time, the teacher only needs to go nearby place that would change the students' absent-minded condition.

Teachers usually lead students to read in middle school. When the teacher is reading, he can go to students' "space zone". If he does like this, he will control the disciplines and correct their wrong pronunciation properly. Moreover, if the teacher does the dictation with walking properly in the classroom, he can draw students' attentions. If a teacher stands on the platform which is from students four to five meters, it's hard to draw their attentions. Some teachers often complain that they cannot get satisfactory teaching effects when they are teaching in multimedia classrooms.

\section{Concrete Application of Body Language in DifFerent Aspects in English Teaching}

\section{A. Application of Using Body Language in Listening}

As we all know, listening constitutes a significant part in our daily communication. To understand others and be understood is a basic purpose in English learning. In this process of training students' listening ability, if teachers use the body language properly, they can achieve better effect. For instance, a teacher can extend his or her arms slowly when he or she says "She lives in a very large house" and open his or her eyes widely with mouth opened when he or she says "She is such a beautiful lady". As a result, the students will have deep impressions that the room is very big and the lady is beautiful.

\section{B. Application of Using Body Language in Speaking}

The spoken language is one of the important ways to communicate with others. Chinese students are very shy. They usually can write and read English very well but cannot speak English, so we should try to develop the students' ability of speaking. How can teachers help students overcome their passive attitudes? Body language can arouse and sustain the students' interests of using and learning English. In fact, they are helped to reach the aim in a certain degree by their teacher's body language. In the English classes, the teachers should not only use body languages themselves, but also ask the students to use them according to different situations. For example, a text about when the new students meet for the first time, and they don't know each other. So teachers can introduce themselves first. During the introduction process, the teachers should use the new words and sentences together with a vivid expression and proper gestures as possible as they can. They smile when they say hello to the class, they shake hands with some students saying "Glad to meet you". When they express their interests, they imitate the actions of dribbling and shooting at the basketball, turning pages to indicate reading. After the teachers' introductions, they can create an environment for the students to practice. Indeed, the application of body language in different situations will help to create an interesting and successful lesson.

\section{Application of Using Body Language in Reading}

Body language is helpful in improving students' reading ability. Here we mainly discuss the usefulness of reading aloud. It can help students to achieve good pronunciation and intonation of English. What's more, it can help them to fully and deeply understand the beauty of the language. As a famous saying goes, a poem is not a poem until it is read. Teachers should tell students to use proper body language whiling reading loudly. For example, pay attention to where to raise or lower our tone, when to speak softly. To achieve better result, we can adapt the strong or soft parts that are used in music teaching. For instance, we use falling tones in declarative sentences, use rising tones and then falling tones in the selective question sentences. At first the students might feel confused as they are not accustomed to it yet. However, with the help of body language, they can master it more easily. For example, when they read a selective question sentence, they put up their hands in rising tone and put down hands in falling tones. After training for some times, whenever they read the sentences, they will use this body language unconsciously. In a word, fluent English with vivid gestures helps to can create a good learning environment, which will surely motivate students' reading ability.

\section{CONCLUSION}

We can see that body language is of helpfulness for English teaching. And if we want to deepen the quality education proceeds, we should clear off the traditional boredom and monotone. English classroom will become a stage for teachers and students. For the purpose that teachers should teach their students in comfortable context. They can change the little classroom into a shop, a hotel, a park, even a hospital. Body language can be a good tool for improving the imaginations of the students and helping teacher express their ideas and language points more vividly. And by the body language, they can express some connotation of language that is difficult to express by mouth. 
Teaching quality and effect is the core of education, and the use of body language can improve the teaching quality of English class. As a matter of fact, most students enjoy an active atmosphere of English learning instead of a boring and serious one. Since enthusiastic participation is the foremost factor in language learning an active and relaxed learning environment is even more important than teaching itself. In an active and lively class, the students are more willing to cooperate with teacher and attend class conscientiously. And most students consider that body language can help then memorize teaching contents to a certain degree.

In classroom, the teachers frequently make use of various kinds of body language combined with words to organize their teaching activities. The use of body language will help teachers express their ideas and thoughts accurately and lively. The purpose is to ensure that students can understand them clearly. Consequently, teaching activities can be carried out accordingly without any misunderstandings or confusion. In addition, the use of body language can improve teachers' enthusiasm, thus reducing students' lassitude in classes, especially in the afternoon classes. And as a result, the English class teaching can be facilitated.

In the future teaching program, the teachers should have visible and audible teaching material like cards and tapes. People can communicate with each other not only through verbal means, but also nonverbal communication. Moreover, the latter plays an important role. Body language is an important part of nonverbal communication. A great attention is paid to the function and effect of the teachers' body language in English class in recent years. Researchers tell us that the effective use of proper body language can greatly improve the relationship between the teachers and the students. What's more, it can enhance students' learning efficiency and cognitive ability. A successful English teacher knows how to make full use of the body languages such as expression, gesture, eye contact and so on in order to get the best teaching effect. Using body language in English class can not only make the teachers and the students know each other well, but create a relaxing studying environment, and activate students' learning interest and deepen their impression and imagination. The use of body language is completely meet the standards of audio-visual teaching principle, and teachers should try to teach in English from the beginning to the end, together with the corresponding body language. In this way, will the students' ability of English be certainly and greatly improved.

\section{REFERENCES}

[1] All, E. D. \& Valete, R. M. (1977). Classroom Techniques: Language and English as a Second Language. New York: Harcourt Brace Jovanovich.

[2] Cooper \& Pamela. (1988). Speech Communication for the Classroom Teaching. New York: Gorsuch Scarisbrick Publishers.

[3] Chen, S. \& Watts, D. (1992). Intercultural Communication. Washington: Anchor Books.

[4] Dubin, F. \& Olshtain, E. (2002). Course Design. Shanghai: Shanghai Foreign Language Education Press.

[5] Guo Xuehua. (1999). My Understanding of Effective English Reading Class Teaching. Gian Teachers' College Journal.4, 56 61.

[6] Hornby, A. S. (2006). Oxford Advanced Learner's English-Chinese Dictionary. Oxford: Oxford University Press.

[7] Mehrabian, A. (1972). Nonverbal Communication. University of Michigan: Aldine Transaction.

[8] Yu Aihong. (2002). Language Transfer and Foreign Language Teaching. Shandong Education and Reach Press. 2, 23-41.

Yuanyuan Tai was born in Heze, China in 1982. She received her MA degree in English language and literature from Qufu University, China in 2012.

She is currently a lecturer in the School of Foreign Languages, Heze University, Heze, China. Her research interests include linguistics and American literature.

Ms.Tai is a member of the Chinese Association of Foreign Language Teachers. 